\title{
Quantification of serum immunoglobulin in rainbow trout Salmo gairdneri under various environmental conditions
}

\author{
N. J. Olesen \& P. E. Vestergård Jørgensen \\ National Veterinary Laboratory, Hangovej 2, 8200 Århus N, Denmark
}

\begin{abstract}
The concentration of serum immunoglobulin in different groups of rainbow trout Salmo gairdneri was measured by means of a single radial immunodiffusion test. The normal IgM concentration was $3.3 \mathrm{mg} \mathrm{ml}^{-1}$ in a group of free-living trout. Hypergammaglobulinaemia was found in PKDinfected fish and in fish from a trout farm with VHS and ERM, while the IgM concentration was low in sera from fish living under aquarium conditions. Individual variations were very pronounced. The purity of reference preparations and the specificity of antisera used were examined by crossed immunoelectrophoresis.
\end{abstract}

\section{INTRODUCTION}

Fish respond to antigenic stimulation by the production of immunoglobulin. So far only one immunoglobulin class is known to occur in teleosts, the characteristics of the class being rather similar to those of mammalian IgM. The molecule is a tretramer consisting of a basic structure of 8 light chains and 8 heavy chains (same molecular weight as the $\mu$-chains of mammals) (Acton et al. 1971, Ellis 1982). The molecular weight of the whole molecule is about 700000 Daltons (13 to $16 \mathrm{~S}$ ).

Most studies concerning the humoral immune response in teleosts have dealt with characteristics of the immune response elicited by known antigens. Only in a few cases has the concentration of total immunoglobulin been measured.

Estimates of total immunoglobulin have been made in serum from coho salmon (Voss et al. 1980), tench, carp and goldfish (Vilain et al. 1984), carp (Richter et al. 1973), brown trout (Ingram \& Alexander 1979) and certain salt-water fish (Fidler et al. 1969, Acton et al. 1971, Legler et al. 1971). Estimates of total IgM in serum from rainbow trout Salmo gairdneri have not, to our knowledge, been published so far.

\section{MATERIALS AND METHODS}

Serum. Blood samples were obtained by puncture of the caudal vein of rainbow trout Salmo gairdneri anaesthetized with $0.2 \%$ Chlorbutol. After clotting overnight at $4{ }^{\circ} \mathrm{C}$ the blood was centrifuged at $1000 \mathrm{~g}$ for $15 \mathrm{~min}$ to obtain serum. The sera were stored at $-20^{\circ} \mathrm{C}$ until examined.

Origin of rainbow trout sera. Sera were obtained from the following groups:

(1) Free-living rainbow trout caught by electrofishing in a Danish stream with good water quality. Water temperature: $10^{\circ} \mathrm{C}$. None of the fish had clinical symptoms of disease but a few were lean, apparently due to infestation with intestinal worms (58 samples). (2) Apparently disease-free rainbow trout in 3 trout farms registered free from viral haemorrhagic septicaemia (VHS) and infectious pancreatic necrosis (IPN) for several years. Water supply was only from boreholes or brooks. Water temperature: $4{ }^{\circ} \mathrm{C}$ (23 samples). (3) Rainbow trout in a farm infected by VHS and enteric redmouth (ERM). Blood was sampled at 4 seasons (water temperatures $19,15,10$ and $4{ }^{\circ} \mathrm{C}$, respectively). Several fish were clinically diseased at blood sampling $(10$ samples at each temperature). (4) Fish in a trout farm 
infected with proliferative kidney disease (PKD). All fish examined had clinical symptoms of that disease. Water temperature: $10^{\circ} \mathrm{C}$ (10 samples). (5) Fish from aquaria. (a) VHS- and IPN-free rainbow trout placed as fry in aquaria with tap-water supply at $10^{\circ} \mathrm{C}$ and kept there for $1 \frac{1 / 2}{2}$ уг (20 samples). (b) VHS- and IPN-free rainbow trout placed in aquaria at a body weight of 50 g, individually tagged (Carlin smolt tags) and bloodsampled at regular intervals between 4 and $56 \mathrm{wk}$ after transfer (29 samples).

Antisera. Antiserum to trout serum was prepared by injecting pooled normal rainbow trout serum into rabbits, first subcutaneously with Freund's incomplete adjuvant, then intravenously without adjuvant. Antiserum to trout IgM was prepared as follows: 'crude' $\operatorname{IgM}$ (in the form of IPN virus neutralizing fractions of trout immune serum [Sepharose $4 \mathrm{~B}$ ]) were injected into rabbits with Freund's complete adjuvant (Jørgensen 1973). The resulting antiserum, which was not monospecific, was reacted in immuno-electrophoresis against purified IgM prepared as described below. Immunoprecipitates were cut out, washed in saline and then injected into rabbits together with Freund's complete adjuvant. The resulting antiserum was monospecific (Thøgersen \& Jørgensen 1976, unpubl.).

Rainbow trout IgM. Purification of rainbow trout IgM was carried out as follows (Thøgersen \& Jørgensen 1976, unpubl.). The immunoglobulin in $5 \mathrm{ml}$ of normal trout serum was precipitated by addition of $1.25 \mathrm{~g}$ $\left(\mathrm{NH}_{4}\right)_{2} \mathrm{SO}_{4}(1.95 \mathrm{M})$, incubation for $20 \mathrm{~h}$ at room temperature and centrifugation at $2500 \mathrm{~g}$ for $30 \mathrm{~min}$. The precipitate was resuspended in $0.9 \% \mathrm{NaCl}$ and submitted to gel-filtration on Sepharose 4B (Pharmacia, Uppsala, Sweden). Protein-containing fractions were examined in Ouchterlony double diffusion tests against rabbit antiserum to trout IgM. Fractions which were positive in that test were subsequently concentrated by dialysis against $5 \%$ PEG- 20000 and then subjected to ion-exchange chromatography on Trisacryl M DEAE (LKB) involving elution with a continuous ionic gradient of $0.1 \mathrm{M}$ to $0.5 \mathrm{M} \mathrm{Cl}^{-}$in $0.1 \mathrm{M}$ Tris. The purity of the different purification steps in the present work were tested by crossed immunoelectrophoresis against rabbit antiserum to normal trout serum. When purity was not achieved the preparation was submitted to a new cycle of gel-filtration and ion-exchange chromatography.

Immunoelectrophoresis (IEP). Purity and strength of antigen and antibody preparations were examined by crossed immunoelectrophoresis with and without intermediate gel. The IEP was carried out as described by Grubb (1983) and Just-Svendsen (1983). Plates: Gel Bond Film (Interkemi, Denmark). Gel: 1\% (w/v) Litex agarose type HSA in Tris/barbitone buffer.

Single radial immunodiffusion test (SRID). The test was carried out as described by Mancini et al. (1965) and Ingild (1983). The agarose gel contained $1 \%$ Litex agarose type HSA in $0.01 \mathrm{M}$ PBS, pH 7.2 supplemented with $4 \%$ PEG-6000 (Just-Svendsen et al. 1983) and $7 \mu$ l rabbit antiserum to trout IgM per $\mathrm{ml}$ agarose gel. Ten $\mu \mathrm{l}$ of trout serum diluted $1: 3$ in $0.01 \mathrm{M}$ PBS was added to each well. The gels were washed, dryed and stained after incubation for $4 \mathrm{~d}$ at room temperature. The diameters of the precipitin rings were measured to the nearest $0.1 \mathrm{~mm}$.

Total serum protein. Protein concentration in trout sera was estimated by means of the Biuret method (Richterrich 1971).

Diagnostic examination of fish. Viral haemorrhagic septicaemia (VHS) and infectious pancreatic necrosis (IPNI) was diagnosed by means of standard virological examination utilizing fish cell cultures. Enteric redmouth (ERM) and proliferative kidney disease (PKD) was diagnosed by routine bacteriological or histological examination, respectively.

\section{RESULTS}

\section{Antiserum to IgM}

The monospecificity of the rabbit antiserum to rainbow trout IgM was indicated by the appearance of only one precipitation line when the antiserum was reacted against normal trout serum in crossed immunoelectrophoresis (Fig. 1).

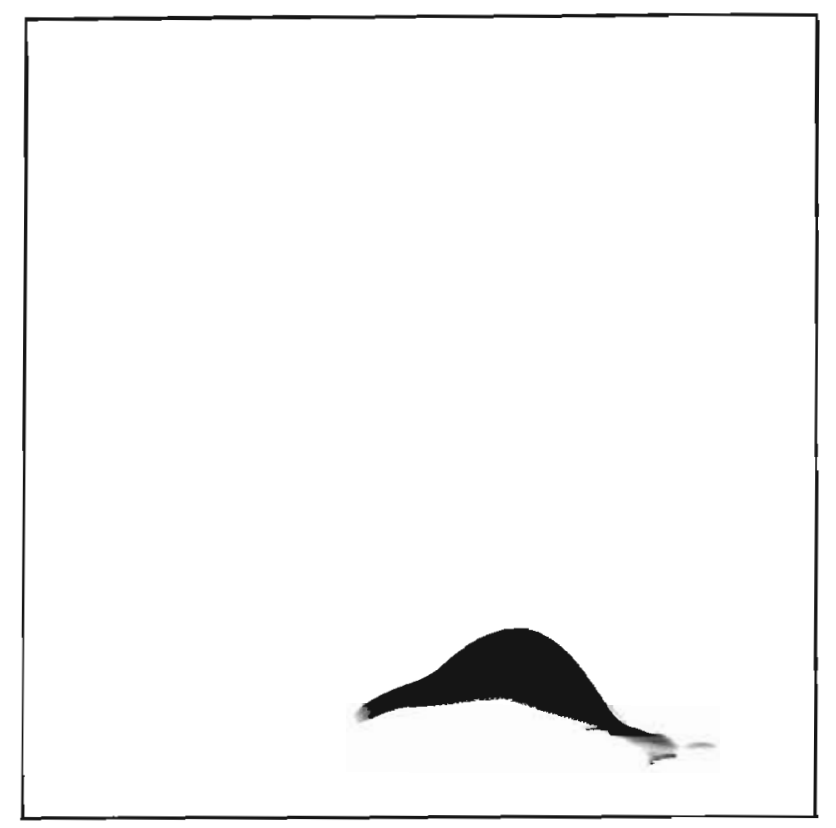

Fig. 1. Crossed IEP. Antigen: normal trout serum $(3.3 \mu \mathrm{l})$. Antibody in gel: rabbit antiserum to trout $\operatorname{IgM}(50 \mu 1 / 4 \mathrm{ml})$ 


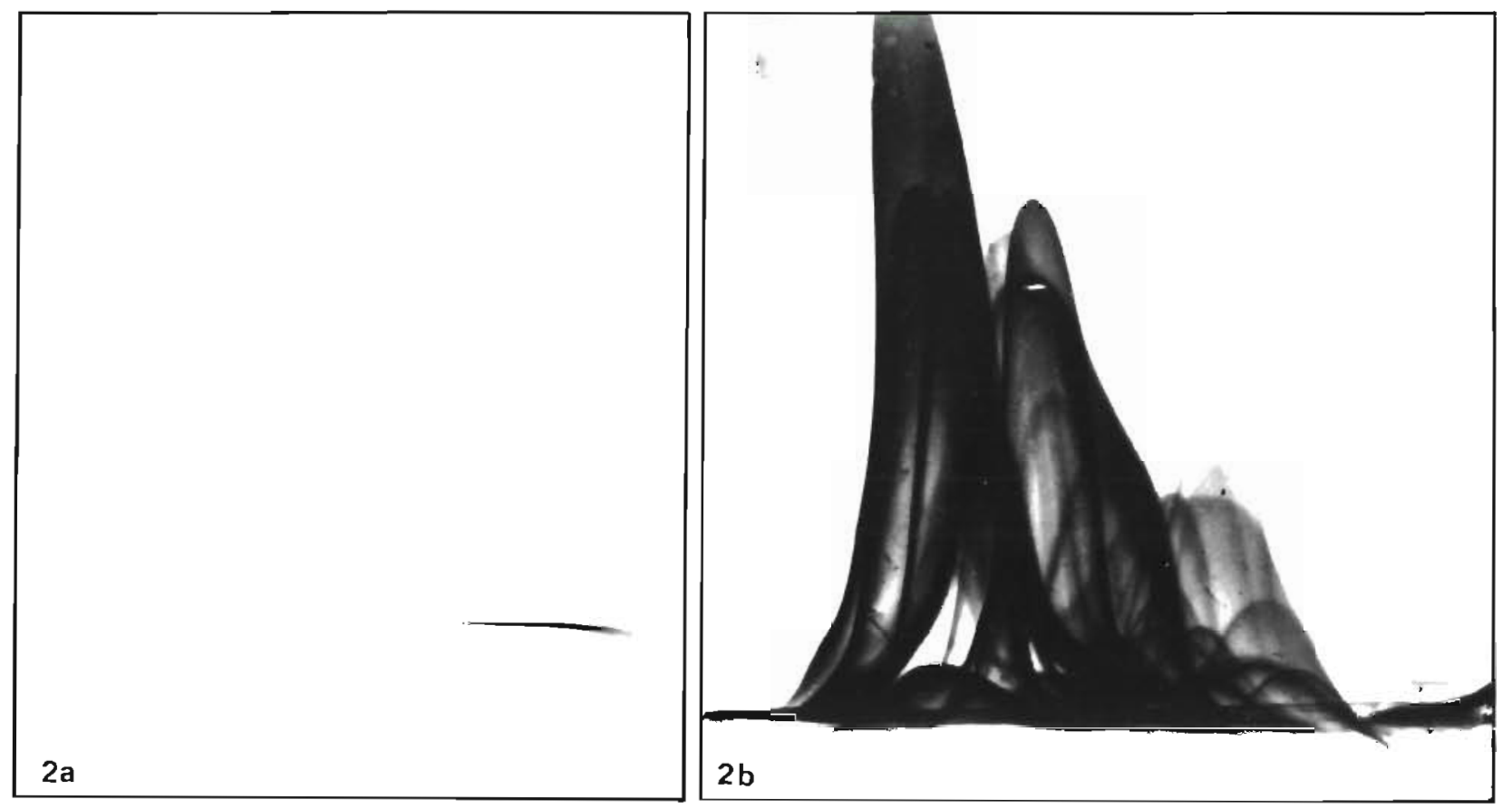

Fig. 2. Crossed IEP. (a) Antigen: reference IgM preparation $\left(10 \mu l_{i} 1 \mathrm{mg} \mathrm{ml}^{-1}\right)$. Antibody in intermediate gel: rabbit antiserum to trout IgM $(20 \mu \mathrm{l} / 1.2 \mathrm{ml})$. Antibody in top gel: rabbit antiserum to normal trout serum $(210 \mu \mathrm{l} / 2.8 \mathrm{ml}$. (b) Antigen: normal trout serum ( $3.3 \mu \mathrm{l})$. Antibody in gel: rabbit antiserum to normal trout serum $(300 \mu \mathrm{l} / 4 \mathrm{ml})$

\section{IgM-reference preparation}

The purity of the IgM preparation which was used as reference IgM in connection with IgM quantification is illustrated in Fig. 2a. It appears that only one precipitation line developed when the preparation was reacted against antiserum to trout serum in crossed immunoelectrophoresis. Fig. $2 \mathrm{~b}$ illustrates the multispecificity of the rabbit antiserum to trout serum used.

\section{SRID test}

A calibration curve for determination of the IgM concentration in trout sera was constructed by plotting 5 different dilutions of reference IgM against the area of their respective precipitation rings in SRID-tests (Fig. 3). This resulted in a straight-line standard curve.

\section{Trout sera}

The mean IgM and protein concentration in sera from 5 groups of rainbow trout is listed in Table 1.

\section{Free-living trout}

The mean IgM concentration in 58 free-living rainbow trout was $3.3 \mathrm{mg} \mathrm{ml}^{-1}$, standard deviation \pm 2.1

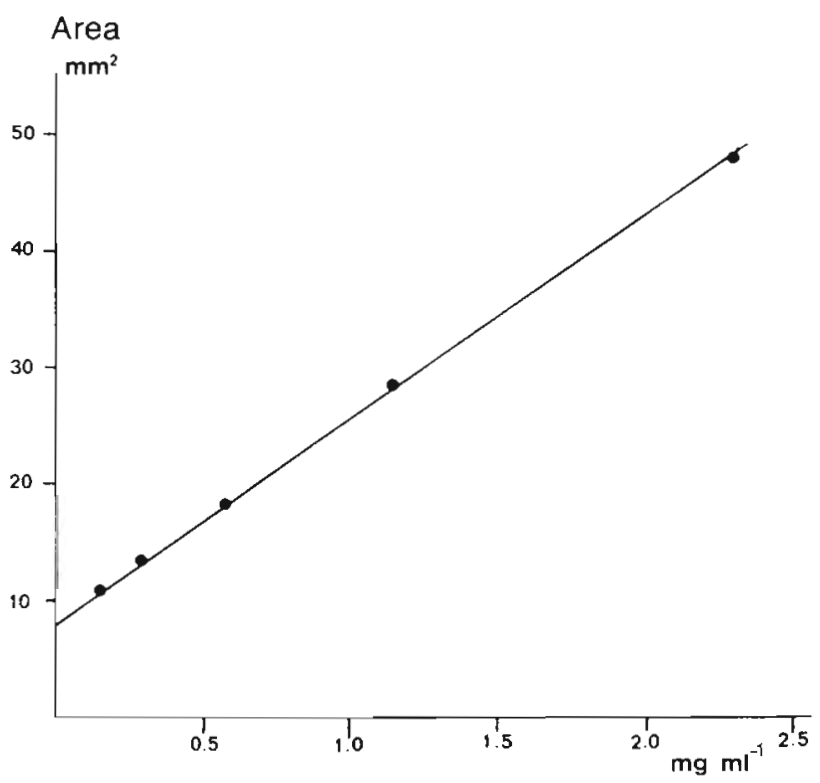

Fig. 3. Salmo gairdneri. Concentration of IgM plotted against area of precipitin rings

$\mathrm{mg} \mathrm{ml}^{-1}$. The highest concentration was $10.6 \mathrm{mg} \mathrm{ml}^{-1}$ and the lowest $1.1 \mathrm{mg} \mathrm{ml}^{-1}$. The individual values are shown in Fig. 4.

Egtved virus (VHS) was isolated from $8 \%$ of the examined fish, and neutralizing antibody against Egtved virus was demonstrated in $18 \%$ of the fish when 
Table 1. Salmo gairdneri. Concentration of IgM and total serum protein in 5 groups of fish

\begin{tabular}{|c|c|c|c|c|c|}
\hline Origin of fish & $\begin{array}{c}\text { Water } \\
\text { temperature } \\
\left({ }^{\circ} \mathrm{C}\right)\end{array}$ & $\begin{array}{l}\text { No. } \\
\text { of fish }\end{array}$ & $\begin{array}{c}\text { Total } \\
\lg M \pm \mathrm{SD} \\
\left(\mathrm{mg} \mathrm{ml^{-1 } )}\right.\end{array}$ & $\begin{array}{l}\text { Total serum } \\
\text { protein } \pm \mathrm{SD} \\
(\mathrm{mg} \mathrm{ml})\end{array}$ & $\begin{array}{c}\text { Total IgM } \\
\text { in \% of total } \\
\text { serum protein }\end{array}$ \\
\hline 1. Stream (free-living fish) & 10 & 58 & $3.3 \pm 2.1$ & $55.4 \pm 10.9$ & $6 \%$ \\
\hline 2. Trout farms (3) without apparent diseases & 4 & 25 & $2.2 \pm 0.7$ & $44.9 \pm 8.3$ & $5 \%$ \\
\hline 3. Trout farm (1) with VHS and ERM & $4-19$ & 40 & $4.2 \pm 1.5$ & $34.3 \pm 8.0$ & $12 \%$ \\
\hline 4. Trout farm (1) with PKD & 15 & 10 & $10.9 \pm 5.3$ & $31.9 \pm 7.1$ & $34 \%$ \\
\hline 5. Aquarium & 10 & 20 & $1.5 \pm 0.4$ & $44.3^{\circ}$ & $3 \%$ \\
\hline - Pool of 20 sera & & & & & \\
\hline
\end{tabular}

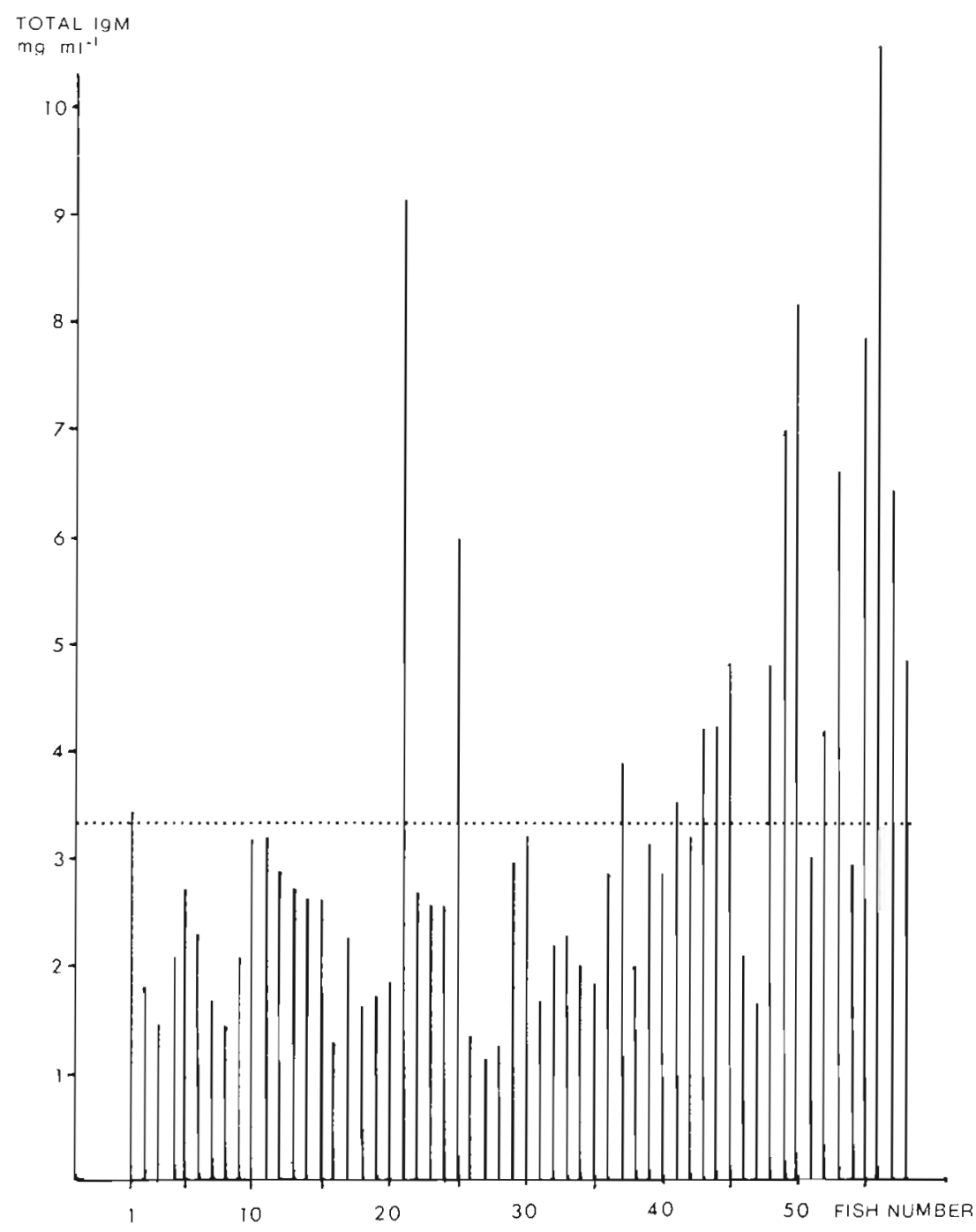

Fig. 4. Salmo gairdneri. Total serum IgM in 58 free-living individuals

their sera were examined by $50 \%$ plaque neutralization tests (cPNT) (Olesen \& Jørgensen 1986). There was no correlation between occurrence of neutralizing antibody against Egtved virus and high serum IgM concentration $\left(\chi^{2}=0.2\right)$, no correlation between Egtved virus infection and low IgM concentration $\left(\chi^{2}=\right.$ 0.04 ) and no correlation between size of the fish and the $\operatorname{IgM}$ concentration $\left(\chi^{2}=0.4\right)$. 


\section{Sera from 5 trout farms}

In Group 2 (Table 1), representing fish from 3 apparently disease-free farms, the mean IgM concentration was $2.2 \mathrm{mg} \mathrm{ml}^{-1}$. Individual values in the group are shown in Fig. 5. The mean IgM concentrations calculated for each of the 3 farms were not significantly different ( $P>0.05$, data not shown).

In Group 3, representing fish from a VHS- and ERMinfected farm, the mean IgM concentration was 4.22 $\mathrm{mg} \mathrm{ml}{ }^{-1}$. There were no significant differences between blood samples collected at different water temperatures $(P>0.05$, data not shown). Individual values for 25 of the fish are shown in Fig. 5.

In Group 4, representing PKD-infected fish with clinical symptoms of the disease, the mean IgM concentration was the highest observed, viz. $10.9 \mathrm{mg} \mathrm{ml}^{-1}$. Individual values are shown in Fig. 5.
Mean IgM concentrations for Groups 2, 3 and 4 were significantly different $(\mathrm{P}<0.001)$.

Fish from aquaria

The IgM concentration in sera from 20 rainbow trout, bled after $1 \frac{1 / 2}{2}$ yr in aquaria with running tap water at $10^{\circ} \mathrm{C}$ (Group 5), is illustrated in Fig. 6. The mean IgM concentration was $1.5 \mathrm{mg} \mathrm{ml}^{-1}$ which is significantly lower than the mean IgM concentration in serum from fish in disease-free trout farms (Group 2) $(\mathrm{P}<0.01)$.

Fig. 7 illustrates the IgM concentration in sera from an individual bled at regular intervals during 1 yr after transfer to an aquarium with tap-water supply $\left(13^{\circ} \mathrm{C}\right)$. The IgM concentration declined from $5.1 \mathrm{mg} \mathrm{ml}^{-1}$ to $1.0 \mathrm{mg} \mathrm{m}^{-1}$ over 56 wk. A similar decline was
Fig. 5. Salmo gairdneri. Total serum IgM for 3 groups of fish: (A) Fish from trout farms without apparent diseases (Group 2); (B) fish from trout farm with VHS and ERM (Group 3); (C) PKD-infected fish (Group 4)

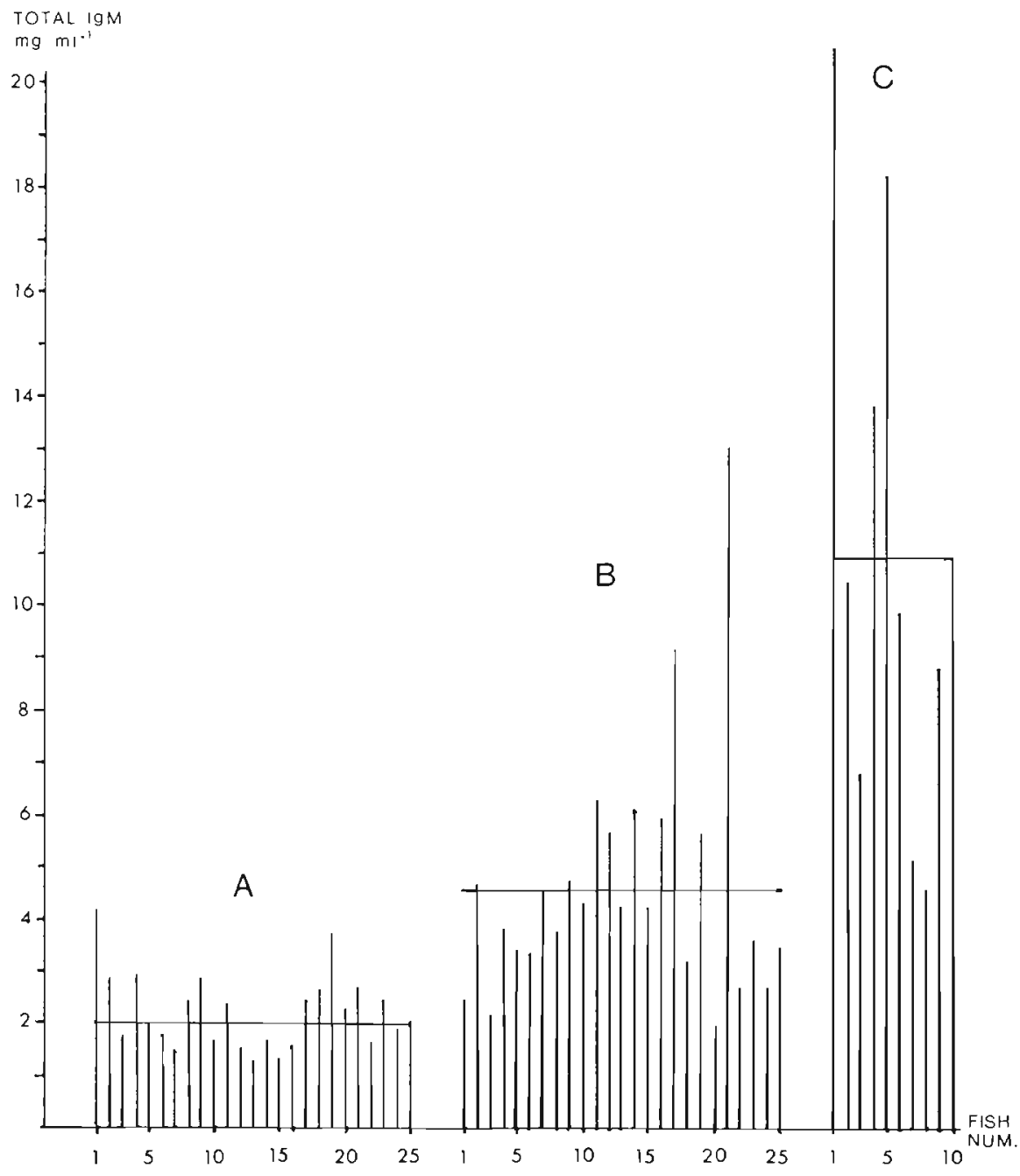




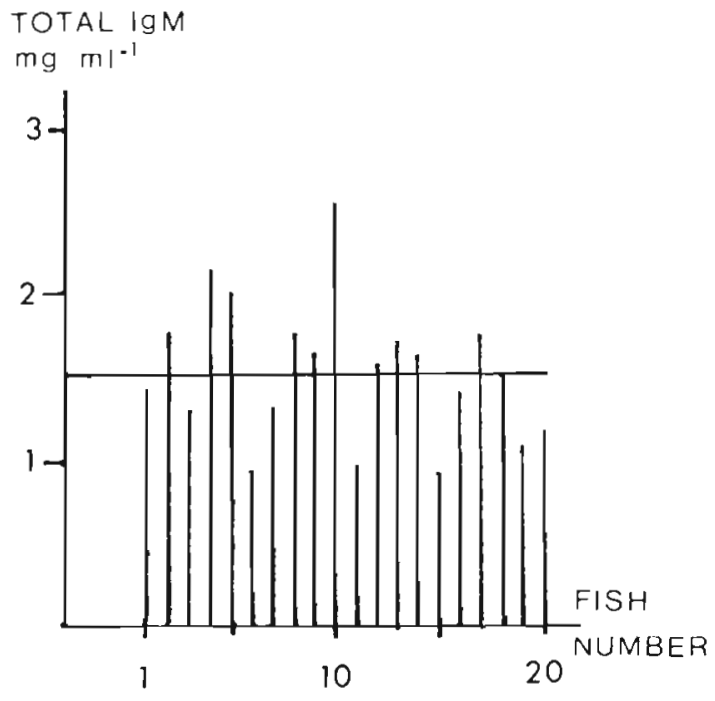

Fig. 6. Salmo gairdneri. Total serum IgM in 20 individuals after $1 \frac{1 / 2}{y r}$ in an aquarium with tap-water supply at $10^{\circ} \mathrm{C}$

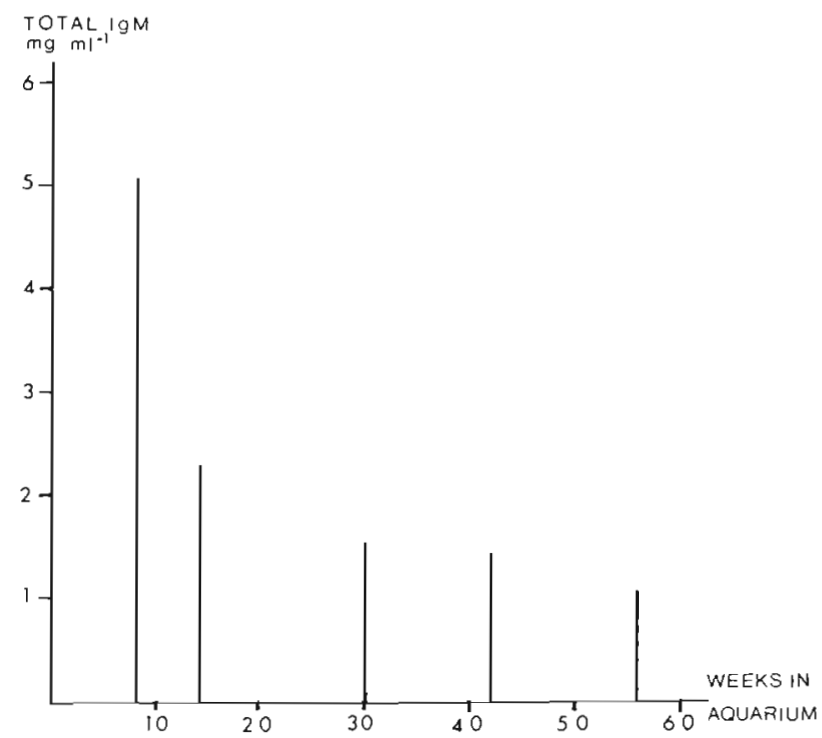

Fig. 7. Salmo gairdneri. Decrease of total IgM in serum from a tagged fish kept under aquarium conditions at $13^{\circ} \mathrm{C}$ for $56 \mathrm{wk}$

observed in sera from several other rainbow trout from the same group (data not shown).

\section{Total serum protein}

As shown in Table 1 the protein concentration in sera from trout in Groups 3 and 4 (infected farms) was significantly lower than the protein concentration in Group 1 (free-living fish) and Group 2 (apparently healthy fish from non-infected trout farms) ( $\mathrm{P}<0.001$ ).

The high IgM concentration in trout from infected trout farms apparently is not due to a relative concen- tration of IgM as a result of exudation of low molecular weight proteins from the vascular system, since no positive correlation was observed between low protein concentration and high IgM concentration.

\section{DISCUSSION}

Quantification of $\operatorname{IgM}$ in the present work is based on 2 assumptions: (1) an IgM preparation is pure if it gives rise to only one precipitation line in crossed immunoelectrophoresis against rabbit antiserum to normal trout serum; (2) the optic density at $280 \mathrm{~nm}$ $\left(\mathrm{OD}_{280}\right)$ of rainbow trout IgM is close to that of mammalian IgM (for which an $O D_{280}$ of 1.5 is equivalent to $1 \mathrm{mg} \mathrm{ml}^{-1}$ (Fasman 1976]). The normal value for the IgM concentration in rainbow trout serum $13.3 \mathrm{mg}$ $\mathrm{ml}^{-1}$ ) was established on the basis of examining 58 free-living fish. Such fish were chosen because they came from an environment that could be considered close to the 'natural' environment of the species.

It is of theoretical as well as practical significance that the $\operatorname{lgM}$ concentration in rainbow trout serum appears to increase in the case of strong antigenic stimulation from the environment, as indicated by the difference between Group 5 and Groups 3 and 4 (Table 1). It is also of interest that infections such as VHS, ERM and PKD seem to lead to hypergammaglobulinaemia combined with hypoproteinaemia. In addition, there were pronounced individual variations in IgM concentrations, i.e. from $0.9 \mathrm{mg} \mathrm{ml}^{-1}$ to $21 \mathrm{mg}$ $\mathrm{ml}^{-1}$ (Fig. 4 to 6). This finding agrees with the remarkable variations previously observed in the intensity of the specific immune response of fish (Dunier 1983, Olesen \& Jørgensen 1986). Awareness of both types of variation is important in designing and evaluating research activities in fish immunology. In particular, the variations indicate that relatively large groups of experimental fish are required to ensure statistically significant results.

Examples of published normal values for serum IgM in different fish species are shown in Table 2. The range is 1.7 to $17.2 \mathrm{mg} \mathrm{ml}^{-1}$. Frequently it is not clear, however, either how many fish were examined or from which type of environment the fish originated. On the basis of the present findings, these values should be considered with some caution. Furthermore, far from all the investigators quoted in Table 2 adequately documented the antigenic purity of the IgM preparation used in the quantification. Use of IgM preparations containing significant amounts of contaminating serum proteins in SRID would inevitably lead to erroneously high $\operatorname{IgM}$ values. The normal $\operatorname{IgM}$ value for rainbow trout serum found in the present study $(3.3$ $\mathrm{mg} \mathrm{ml} \mathrm{ml}^{-1}$ ) is close to the $2.1 \mathrm{mg} \mathrm{ml} \mathrm{m}^{-1}$ reported from 
Table 2. IgM concentration in serum of different fish species

\begin{tabular}{|lccc|}
\hline \multicolumn{1}{|c}{ Fish species } & $\begin{array}{c}\text { IgM } \\
\text { concentration } \\
\left(\mathrm{mg} \mathrm{m}^{-1}\right)\end{array}$ & $\begin{array}{c}\text { IgM conc in } \\
\text { \% of total } \\
\text { serum protein }\end{array}$ & Source \\
\hline Goldfish Carassius auratus & 4.7 & 18 & Vilain et al. (1984) \\
Tench Tinca tinca & 9.1 & 17 & - \\
Carp Cyprinus carpio & 4.8 & 21 & Richter et al. (1973) \\
Carp Cyprinus carpio & 1.7 & 6 & Voss et al. (1980) \\
Coho salmon Oncorhynchus kisutch & - Alexander (1979) \\
Brown trout Salmo trutta & 2.1 & 10 & Fidler et al. (1969) \\
Nurse shark Ginglymostoma cirratatum & 12.3 & 40 & Acton et al. (1971) \\
(neonatal) & 17.2 & 47 & Legler et al. (1971) \\
Paddlefish Polyodon spathula & 3.3 & 6 & Present paper \\
Rainbow trout Salmo gairdneri & & & \\
\hline
\end{tabular}

Coho salmon (Voss et al. 1980) but only half of that found in brown trout (Ingram \& Alexander 1979).

\section{LITERATURE CITED}

Acton, R. T., Weinheimer, P. F., Dupree, H. K., Russel, T. R., Wolcott, M., Evans, E. E., Schrohenloher, R. E., Bennet, J. C. (1971). Isolation and characterization of the immune macroglobulin from the paddlefish, Polyodon spathula. J. biol. Chem. 246: 6760-6769

Dunier, M. (1983). La production d'anticorps sériques chez la truite Arc-en-Ciel (Salmo gairdneri): Influence du rappel et des adjuvans. Thèse présenté à L'Institut Nationale Agronomique, Paris, Grignon

Ellis, A. E. (1982). Differences between the immune mechanism of fish and higher vertebrates. In: Roberts, R. J. (ed.) Microbial diseases of fish. Academic Press, London and New York, p. 1-30

Fasman, G. D. (1976). Handbook of biochemistry and molecular biology, 3rd edn. CRC Press, Cleveland, Ohio, Sec. A., Vol. 2, p. 456

Fidler, J. E., Clem, L. W., Small, P. A. (1969). Immunoglobulin synthesis in neonatal nurse sharks (Ginglymostoma cirratatum). Comp. Biochem. Physiol. 31: 365-371

Grubb, A. O. (1983). Crossed immunoelectrophoresis. Scand. J. Immunol. 17, suppl. 10: 113-124

Ingild, A. (1983). Single radial immunodiffusion. Scand. J. Immunol. 17, suppl. 10: 113-124

Ingram, G. A., Alexander, J. B. (1979). The immunoglobulin of brown trout, Salmo trutta, and its concentration in serum of antigen stimulated and non-stimulated fish. J. Fish Biol. 14: $249-260$
Just-Svendsen, P., Wecke, B., Johansson, B.-G. (1983). Immunoprecipitation-gel-techniques: Chemicals, solutions, equipment and general procedures. Scand. J. Immunol. 17, suppl. 10: 3-20

Jorgensen, P. E. V. (1973). The nature and biological activity of IPN virus neutralizing antibodies in normal and immunized rainbow trout (Salmo gairdneri). Arch. ges. Virusforsch. 42: 9-20

Legler, D. W., Weiheimer, P. F., Acton, R. T., Dupree, H. K., Russel, T. R. (1971). Humoral immune factors in the paddlefish, Polyodon spathula. Comp. Biochem. Physiol. 38B; 523-527

Mancini, G., Carbonara, A. O., Heremans, J. F. (1965). Immunochemical quantitation of antigens by single radial immunodiffusion. Immunochemistry 2: 235

Olesen, N. J., Jørgensen, P. E. V. (1986). Detection of neutralizing antibody to Egtved virus in rainbow trout (Salmo gairdneri) by plaque neutralization test with complement addition. $\mathrm{J}$. appl. Ichthyol. 2: 33-41

Richter, R., Frenzel, E. M., Hadge, D., Kopperschager, G., Ambrosius, H. (1973). Strukturelle und Immunchemische Untersuchungen am Immunglobulin des Karpfens (Cyprinus carpio L.). I. Analyse am gesamtmolekül. Acta. Biol. med. Germ. 30: 735

Richterich, R. (1971). Klinische Chemie (3rd edn). S. Karger, Basel, p. 305-309

Vilain, C., Wetzel, M.-C., Du Pasquier, L., Charlemagne, L. (1984). Structural and functional analysis of spontaneous antinitrophenyl antibodies in three cyprinid fish species: carp (Cyprinus carpio), goldfish (Carassius auratus) and tench (Tinca tinca). Dev. Comp. Immunol. 8: 611-622

Voss, E. W., Groberg, W. J., Fryer, J. L. (1980). Metabolism of Coho salmon Ig. Catabolic rate of Coho salmon tetrameric Ig in serum. Molec. Immunol. 17: 445-452 